\title{
Nematodes as indicators of shrimp farm impact on an amazonian estuary (Curuçá, Pará, Brazil)
}

\author{
Virag Venekey ${ }^{l *}$, Tatianne Pereira Gomes de Melo ${ }^{l}$
}

\author{
${ }^{1}$ Universidade Federal do Pará \\ (Av. Augusto Corrêa, 01. Guamá - Belém - PA, Brazil. CEP: 66075-110) \\ *Corresponding author: venekey@ufpa.br
}

\section{ABstract}

Shrimp farming reduces demand on wild fishery stocks and avoids environmental damage resulting from fishing practices, however, it has the potential to affect the water quality if not properly managed. In this study the impacts of a shrimp farm in an Amazonian estuary were evaluated, focusing on changes in nematodes regarding taxonomic composition, richness, density and diversity. Sampling was conducted in August 2004 (dry season) and January 2005 (rainy season) in the river at stations situated upstream and downstream at different distances from the main source of farm effluent discharge. Thirty-eight genera were recorded with Terschellingia dominating in the dry season and Terschellingia, Daptonema, Ptycholaimellus and Gomphionema in the rainy season. Abundances were within the range recorded in other estuaries and together with genera richness and diversity showed a strong temporal pattern with significantly higher values in the rainy season. No clear patterns of changes were observed at the stations. Some signs of organic enrichment were detected but they were not yet intense, probably a consequence of the strong local hydrodynamics and the age of the shrimp farm, which was just starting its operation. We recommend that in future studies on farming impacts a combination of factors, beyond the physical and chemical parameters of the water and sediments or taxonomic refinement, should be taken into account such as the duration of the operation of the farm, the area occupied by ponds and the farm's production. Furthermore, we also believe that nematodes are a useful tool for evaluating aquaculture impacts due to the ease of sampling and because they are organisms at the base of marine food chain.

Descriptors: Meiobenthos, Impact, Aquaculture, Amazon Region.

\section{Resumo}

A carcinocultura reduz a demanda de estoques pesqueiros naturais e evita o dano ambiental resultante da pesca. Entretanto, tem o potencial de afetar a qualidade da água quando não manejada apropriadamente. Nesse trabalho, os impactos de uma fazenda de carcinocultura foram avaliados em um estuário amazônico focando nas mudanças de composição taxonômica, riqueza, densidade e diversidade de Nematoda. A amostragem ocorreu em agosto de 2004 (período seco) e janeiro de 2005 (período chuvoso) a montante e jusante em locais situados a diferentes distâncias do principal local de descarga de efluentes da fazenda. Trinta e oito gêneros foram encontrados, com dominância de Terschellingia na estação seca e Terschellingia, Daptonema, Ptycholaimellus e Gomphionema na estação chuvosa. As abundâncias foram similares às encontradas em outros estuários e, juntamente com a riqueza e diversidade, apresentaram um forte padrão sazonal com valores significativamente maiores na estação chuvosa. Nas estações de coleta não foram encontrados padrões claros de mudanças. O estuário de Curuçá mostrou alguns sinais de enriquecimento orgânico ainda não intensos, provavelmente devido à forte hidrodinâmica local e à idade da fazenda, que recentemente começou suas atividades. Recomenda-se que no futuro os trabalhos sobre impactos de cultivo, além dos parâmetros físico-químicos da água e sedimento ou refinamento taxonômico dos organismos estudados, considerem também outros fatores, tais como tempo de estabelecimento do cultivo, área ocupada pelos tanques e sua taxa de produção. Além disso, os dados apontam que a nematofauna pode ser uma ferramenta útil na avaliação de impactos da aquicultura devido sua fácil coleta e por serem organismos na base da cadeia alimentar marinha.

Descritores: Meiobentos, Impacto, Aquacultura, Região Amazônica. 


\section{INTRODUCTION}

Shrimp farming reduces demand on wild fishery stocks and avoids the environmental damage resulting from fishing practices. However, shrimp farming has the potential to adversely affect receiving water quality if not properly managed (NAYLOR et al., 2000). In the last years, shrimp farming has been increasing in tropical regions, especially in South Asia and Latin America (PAQUOTTE et al., 1998). The expansion of these activities in tropical and subtropical zones is due to the climate which is favorable to the farming of aquatic species and the availability of space for the construction of ponds (PÁEZ-OSUNA, 2001).

As a general rule, marine shrimp farms have been developed in mangrove areas. Most farms use a semiintensive system, bringing post-larval forms to maturity in earth ponds. The stocking densities range from 10 to 30 animals. $^{-2}\left(100,000-300,000\right.$ animals.ha $\left.{ }^{-1}\right)$, artificial protein-rich food is provided, ponds are fertilized to stimulate productivity and water is discharged from these shrimp ponds into the coastal ecosystem as part of the water exchange which occurs when ponds are drained (BOYD, 2000; BARRAZA-GUARDADO et al., 2013).The expansion of shrimp farming in estuaries has resulted in environmental and social-economic impacts like mangrove deforestation, water contamination by the farm effluent discharges, salinization of aquifers, the escape of exotic animals and the extinction of many local species (PRIMAVERA, 1997; BERLANGA-ROBLES et al., 2011). Organic (animal parts) and inorganic residues (fertilizers) are discharged directly in the effluents resulting in nutrient and organic matter enrichment which modify the local water's and sediment's physical-chemical characteristics and consequently result in the modification of benthic community structures (FOLKE; KAUTSKY, 1992; WOLANSKI et al., 2000).

In Brazil, shrimp farming began in the 1980s and after a period of technological validations and enhancements the country rose to the position of world leader in productivity in 2003 (ROCHA, 2010). The shrimp farming agribusiness has assumed increasing social importance, especially in the northeastern region, which accounts for $95 \%$ of national production (ROCHA, 2010). In North Brazil, including the Amazonian region, shrimp farms are not well developed and they are mostly characterized by small and medium sized farms which produce for local consumption (MARTINELLI; FREITAS-JÚNIOR, 2007). The main species farmed are the freshwater species Macrobrachium rosembergii and Macrobrachium amazonicum and the marine species Litopenaeus vannamei (ABCC, 2013). In Pará State only five medium-sized marine shrimp farms were functioning at the time of this study (MARTINELLI; FREITAS-JÚNIOR, 2007).

In mangrove areas meiofauna are excellent organisms for studying pollution as these animals facilitate the biomineralization of organic matter, serve as food for higher trophic levels and show high sensitivity to anthropogenic inputs (COULL; CHANDLER, 1992). Furthermore, their intimate association with and dependence on sedimentary environments, high abundance and holobenthic life-cycle make them a good tool to assess the effects of contaminants (COULL; CHANDLER, 1992). Among meiobenthic organisms nematodes are usually dominant in mangrove areas (GIERE, 2009) and they have been largely used as indicators of organic disturbance because of their high densities and high taxonomic diversity (BONGERS; FERRIS, 1999). They can show sensitivity to oil spills (DANOVARO et al., 1995), drilling activities (GEE et al., 1992; NETTO et al., 2009), inorganic fertilizer (SANTOS et al., 1999; FERREIRA et al., 2015) and even non-organic disturbances such as tourist trampling (SARMENTO et al., 2013).

Meiofauna has also been used in studies of environmental impact caused by worldwide farming, such as that of mussel farms (MIRTO et al., 2000; DANOVARO et al., 2004; PINTO et al., 2007; MAHMOUDI et al., 2008; NETTO; VALGAS, 2010), fish farms (MAZZOLA et al., 1999; LA ROSA et al., 2001; MIRTO et al., 2002; SUTHERLAND et al., 2007; GREGO et al., 2009; RIERA et al., 2011; MIRTO et al., 2012; RIERA et al., 2012) and that of seaweed (ÓLAFSSON et al., 1995). These studies have used the whole meiofauna community, or isolated groups as Nematoda and Copepoda, and as a general rule the faunal responses are rather uniform with an initial enrichment in meiofaunal numbers and a decrease in diversity with an increase in the dominance of a few species (GIERE, 2009).

Some studies have been conducted to evaluate possible impacts of the organic pollution caused by shrimp farms in mangrove areas (TROTT; ALONGI, 2000; McKINNON et al., 2002; CONSTANZO et al., 2004; SOARES et al., 2004; RODRIGUEZ-GALLEGO et al., 2008; THOMAS et al., 2010; MOLNAR et al., 2013). In those studies planktonic and benthic organisms (mostly macrofauna) were used as indicators of environmental stress. Few studies have, however, focused on the impact of shrimp farms on meiofauna communities (PAULA et 
al., 2006; DEBENAY et al., 2009; PATRONA et al., 2012) and as far as we know those of NETTO and MEURER (2007) and SANTOS et al. (2007) are the only ones using nematodes at low taxonomic levels (genera/species) but even so they do not present complete information about nematode assemblages. The present study used nematodes as biological indicators of the impacts of a shrimp farm in an Amazonian estuary (Curuçá, Pará, Brazil) with the main objective of verifying how the farm's impacts and the changes produced in the assemblages' structure affected taxonomic composition (at genus level), richness, density and diversity.

\section{MATERIAL AND METHODS}

The study area is located in the Curuçá estuary (Northern Brazil), $150 \mathrm{~km}$ from Belém, being limited to the North by the Atlantic Ocean and forming part of the second largest continuous mangrove unit of the world (KJERFVE; LACERDA, 1993) (Figure 1). The Curuçá estuary is formed by the confluence of the Curuçá and Muriá rivers. The climate is Amazon equatorial according to the Köppen system, and is characterized by high temperatures (average value of $27^{\circ} \mathrm{C}$ ), small temperature amplitude and an abundant rainfall regimen that exceeds $2500 \mathrm{~mm}$.year ${ }^{-1}$. The months from December to June are rainy (the rainy season) with rainfall rates above $300 \mathrm{~mm}$. month ${ }^{-1}$ and from July to November (the dry season) the rainfall decreases to $60 \mathrm{~mm}$. month $^{-1}$ (MORAES et al., 2005). Salinity ranges from 7 (rainy period) to 22 (dry period) (FLAMBOT, 1988). Bottom sediments are very fine with less than $10 \%$ of sand (PAULA et al., 2006).
The shrimp farm producing Litopenaeus vannamei, where the samplings were carried out, used a semi-intensive system and had been established five years before the time of sampling. The farm is located at the side of the Curuçá river's main channel and covers an area of approximately 55 ha (12ha of ponds). Three production cycles of 90 days are undertaken annually and the average production is of 20 to 60 tons per cycle (MARTINELLI; FREITASJÚNIOR, 2007). A study carried out by PEREIRA et al. (2007) showed that the waters around the effluent discharge outlet presented small variations between seasons, and had characteristics of typical estuarine non-polluted waters as regards $\mathrm{pH}$ (7.2-8), salinity (around 27), turbidity (6.7-9.4 NTU), particulate suspended matter (around 52 mg.L ${ }^{-1}$ ), dissolved oxygen (above $7.5 \mathrm{mg} . \mathrm{L}^{-1}$ ), total nitrogen (1-2.2 $\mu \mathrm{M})$ and total phosphorus (0.3-0.8 $\mu \mathrm{M})$.

Samples were collected in August 2004 (dry season) and January 2005 (rainy season) in the river, both upstream (A) and downstream (B) from the farm at localities situated at $0 \mathrm{~m}$ (Station 1), 30m (Station 2) and $200 \mathrm{~m}$ (Station 3) from the main outlet of farm effluent discharge. At each sampling site four meiofauna replicates were collected using a corer $(2 \mathrm{~cm}$ inner diameter and $5 \mathrm{~cm}$ deep) and fixed in $4 \%$ formaldehyde solution. Samples for organic matter, nitrogen and phosphorous analysis were collected to a depth of $10 \mathrm{~cm}$ ( $5 \mathrm{~cm}$ inner diameter) and kept on ice in the dark at low temperatures in the laboratory $\left(-18^{\circ} \mathrm{C}\right)$.

The samples were treated using the routine methods for meiofauna (manual centrifugation and humid sieving using 0.5 and $0.063 \mathrm{~mm}$ sieves) suggested by ELMGREN (1973). The nematodes were sorted using Dollfus plates and

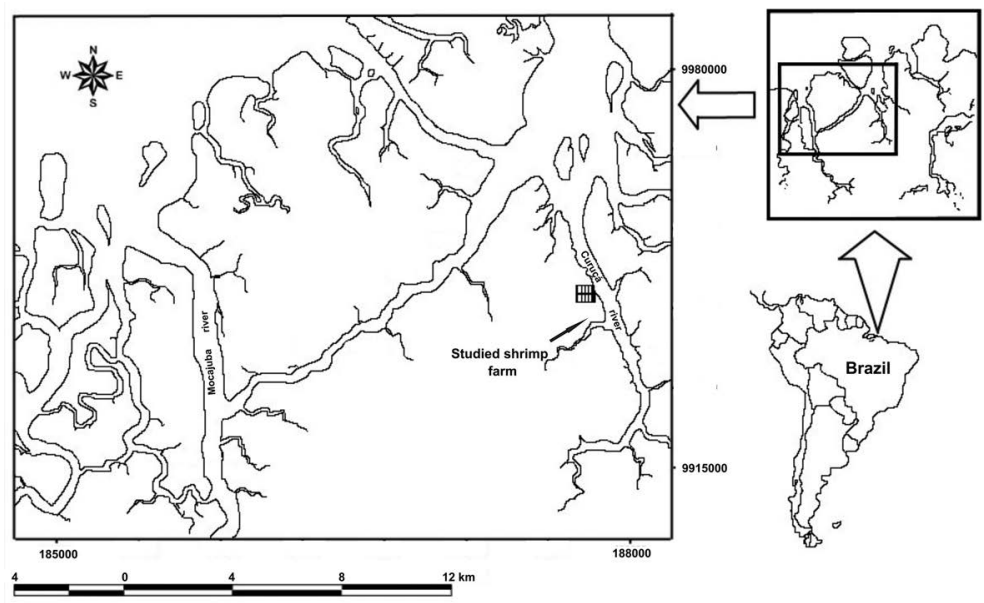

Figure 1. Map of Curuçá estuary (Brazil) indicating the shrimp farm studied. 
a stereoscopic microscope. Permanent slides were made following DE GRISSE (1969) and the nematodes were identified to genus level with the use of the pictorial keys of WARWICK et al. (1998). Genera were assigned to feeding types according to the classification of WIESER (1953) based on the structure of buccal cavity: $1 \mathrm{~A}$ - selective deposit feeders without buccal cavity, 1B - non-selective deposit feeders with an unarmed buccal cavity, 2A - epigrowth feeders with a buccal cavity armed with small teeth and $2 \mathrm{~B}$ - predators or omnivorous with a large strongly armed buccal cavity. Organic matter content was estimated by burning sediments at $450^{\circ} \mathrm{C}$ for $24 \mathrm{~h}$ (WALKLEY; BLACK, 1934). Total nitrogen and total phosphorus were measured by MURPHY and RILEY's (1958) method.

Nematode richness ( $\mathrm{S}$ - total number of genera), density $\left(\mathrm{N}\right.$ - number of individuals per $\left.10 \mathrm{~cm}^{2}\right)$ and diversity $\left(\mathrm{H}^{\prime}-\right.$ Shannon-Wiener) were calculated for each sample. Two-way ANOVA and two-way PERMANOVA were employed to compare nematode assemblages as a whole and individual assemblage descriptors as between seasons and sampling stations. Abundance data per sample were log $(x+1)$ transformed and the resemblance matrix was calculated using Bray Curtis similarity. In those cases in which the $A N O V A$ and PERMANOVA results were significant $(p<0.05)$, pairwise a posteriori comparisons were performed using Tukey's test and permutations, respectively. Multidimensional scaling analysis (MDS) was used to organize samples according to their sampling occasion and site. Statistical analyses were applied using STATISTICA 8, PRIMER 6 and PERMANOVA+ for PRIMER programs.

\section{RESULTS}

The characteristics of the sediment at the different stations are presented in Table 1. In a general view downstream stations (B) had higher values of organic matter, nitrogen and phosphorus than upstream stations (A). Organic matter varied from 0.16 to $0.48 \%$ in August with higher values at stations $2 \mathrm{~B}$ and $3 \mathrm{~B}$. During January organic matter attained higher values, varying from 0.26 to $0.53 \%$, with the highest value occurring at the central station (1). Nitrogen presented the same variation of values between stations in both seasons (from 0.14 to $0.19 \%$ ) but in August the highest value was measured at central station 1 and in January at the downstream stations 2B and 3B. Phosphorus varied from 30.0 to $39.0 \mathrm{mg} / \mathrm{dm}^{3}$ in August (the highest value being recorded at station 2A) and from 21.0 to $35.0 \mathrm{mg} / \mathrm{dm}^{3}$ in January (the highest value being found at station $3 \mathrm{~B}$ ). Although some variation was observed, no clear differences were observed for sediment characteristics between the seasons.

The nematode assemblage of the Curuçá consisted of 38 genera (Table 2). Although we did not identify them to species level, we observed that both the upstream and downstream stations presented the same group of species. Six genera accounted for $80 \%$ of all the nematodes identified: Terschellingia, Sabatieria, Daptonema, Gomphionema, Ptycholaimellus and Metachromadora. During the dry season (August), 25 genera were found with a dominance of Terschellingia, a selective deposit feeder, at all the stations, whereas in the rainy season (January) 33 genera (20 in common with August) were found, with a dominance of Terschellingia only at stations $2 \mathrm{~A}$ and $3 \mathrm{~B}$. Further stations were each, during the rainy season, dominated by different genera: Daptonema, a non-selective deposit feeder, at 1; Ptycholaimellus, an epigrowth feeder, at $2 \mathrm{~B}$ and Gomphionema, an omnivorous, at 3A. The genus Sabatieria, a non-selective deposit feeder, was the most consistent taxon throughout the study, figuring always among the most abundant genera at all the stations and on all the sampling occasions.

Richness varied significantly between seasons, stations and the interactions between seasons and stations (Table 3 ). Richness was higher during the rainy season than the dry season, the exception being station 2A (Figure 2). Posthoc comparisons showed significant differences between stations 1 and $3 \mathrm{~A}$ during the dry season and $2 \mathrm{~A}$ and $2 \mathrm{~B}$ during the rainy season (Table 4). Abundances were much lower in August than in January, with values ranging from 320.06 to $1410.15 \mathrm{ind} / 10 \mathrm{~cm}^{2}$ and from 1753.97 to 3441.07

Table 1. Sediment characteristics in the proximity of a shrimp farm in Curuçá estuary. D1 =0m; D2 = 30m; D3 = 200m. $\% \mathrm{OM}=$ percentage of organic matter; $\mathrm{N}_{\text {total }}(\%)=$ percentage of total Nitrogen; $\mathrm{P}_{\text {total }}\left(\mathrm{mg} / \mathrm{dm}^{3}\right)=$ total phosphorus

\begin{tabular}{lcccccccccc}
\hline & \multicolumn{4}{c}{ Dry Season (August) } & \multicolumn{5}{c}{ Rainy Season (January) } \\
& $3 \mathrm{~A}$ & 2A & 1 & 2B & 3B & 3A & $2 \mathrm{~A}$ & 1 & $2 \mathrm{~B}$ & $3 \mathrm{~B}$ \\
\hline $\mathrm{OM}(\%)$ & 0.31 & 0.16 & 0.40 & 0.48 & 0.48 & 0.26 & 0.34 & 0.53 & 0.32 & 0.43 \\
$\mathrm{~N}_{\text {total }}(\%)$ & 0.14 & 0.16 & 0.19 & 0.17 & 0.16 & 0.14 & 0.15 & 0.14 & 0.19 & 0.19 \\
Ptotal $\left(\mathrm{mg} / \mathrm{dm}^{3}\right)$ & 30.0 & 39.0 & 32.0 & 34.0 & 35.0 & 23.0 & 29.0 & 21.0 & 32.0 & 35.0 \\
\hline
\end{tabular}


Table 2. Mean density $\left(\mathrm{Ind} / 10 \mathrm{~cm}^{2}\right)$ and feeding types (Wieser, 1953) of nematode genera in the proximity of a shrimp farm in Curuçá estuary.

\begin{tabular}{|c|c|c|c|c|c|c|c|c|c|c|}
\hline \multirow{2}{*}{ Genera/Feeding type } & \multicolumn{5}{|c|}{ Dry Season (August) } & \multicolumn{5}{|c|}{ Rainy Season (January) } \\
\hline & $3 \mathrm{~A}$ & $2 \mathrm{~A}$ & 1 & $2 \mathrm{~B}$ & $3 \mathrm{~B}$ & $3 \mathrm{~A}$ & $2 \mathrm{~A}$ & 1 & $2 \mathrm{~B}$ & $3 \mathrm{~B}$ \\
\hline Terschellingia $1 \mathrm{~A}$ & 219.26 & 284.36 & 354.08 & 417.11 & 615.14 & 872.59 & 478.40 & 271.77 & 108.48 & 570.72 \\
\hline Sabatieria 1B & 15.28 & 49.30 & 126.26 & 266.37 & 323.44 & 627.85 & 127.49 & 385.04 & 185.55 & 442.57 \\
\hline Daptonema 1B & 15.67 & 181.92 & 286.66 & 299.82 & 62.49 & 84.48 & 422.02 & 683.05 & 11.61 & 56.90 \\
\hline Gomphionema 2B & 0.00 & 96.26 & 0.00 & 92.64 & 56.68 & 1204.31 & 264.89 & 22.65 & 47.39 & 256.85 \\
\hline Ptycholaimellus 2A & 57.91 & 121.32 & 312.28 & 137.52 & 126.00 & 80.02 & 36.76 & 191.55 & 342.48 & 85.62 \\
\hline Metachromadora 2B & 0.00 & 1.24 & 4.89 & 0.00 & 19.57 & 19.18 & 414.42 & 405.03 & 231.07 & 114.13 \\
\hline Sphaerolaimus 1B & 1.98 & 6.09 & 72.44 & 24.19 & 55.57 & 72.25 & 0.00 & 316.05 & 220.17 & 71.19 \\
\hline Pseudochromadora 2A & 0.00 & 15.58 & 56.48 & 0.00 & 24.37 & 38.36 & 245.27 & 251.72 & 82.59 & 14.22 \\
\hline Pseudolella 1B & 0.00 & 0.00 & 5.69 & 12.09 & 18.00 & 176.73 & 58.92 & 0.00 & 0.00 & 0.00 \\
\hline Hypodontolaimus 2B & 0.00 & 0.00 & 0.00 & 0.00 & 0.00 & 130.60 & 0.00 & 20.06 & 89.51 & 14.29 \\
\hline Pareudiplogaster 2A & 0.00 & 0.00 & 0.00 & 0.00 & 0.00 & 44.37 & 0.00 & 20.06 & 28.92 & 57.10 \\
\hline Marylynnia 2A & 0.00 & 0.00 & 18.94 & 0.00 & 0.00 & 0.00 & 12.25 & 40.11 & 16.95 & 0.00 \\
\hline Anoplostoma 1B & 0.00 & 0.00 & 13.25 & 0.00 & 18.00 & 0.00 & 0.00 & 0.00 & 51.48 & 0.00 \\
\hline Dorylaimopsis 2B & 0.00 & 5.53 & 0.00 & 3.31 & 36.00 & 36.47 & 0.00 & 0.00 & 0.00 & 0.00 \\
\hline Parasphaerolaimus 2B & 0.00 & 0.00 & 0.00 & 0.00 & 0.00 & 18.23 & 0.00 & 0.00 & 45.48 & 14.23 \\
\hline Oxystomina 1A & 0.00 & 1.24 & 5.69 & 0.00 & 0.00 & 0.00 & 0.00 & 20.06 & 35.20 & 14.23 \\
\hline Viscosia 2B & 0.00 & 11.29 & 0.00 & 0.00 & 0.00 & 0.00 & 12.25 & 20.06 & 29.88 & 0.00 \\
\hline Haliplectus 1A & 0.00 & 0.00 & 0.00 & 0.00 & 18.00 & 0.00 & 0.00 & 2.60 & 49.57 & 0.00 \\
\hline Spirinia 2A & 0.00 & 1.24 & 5.69 & 0.00 & 0.00 & 0.00 & 0.00 & 39.81 & 8.94 & 0.00 \\
\hline Spilophorella 2A & 0.00 & 0.00 & 0.00 & 0.00 & 0.00 & 0.00 & 0.00 & 0.00 & 48.06 & 0.00 \\
\hline Campylaimus 1A & 4.99 & 0.00 & 21.37 & 0.00 & 17.45 & 0.00 & 0.00 & 0.00 & 2.67 & 0.00 \\
\hline Paracomesoma 2A & 0.00 & 4.29 & 0.00 & 0.00 & 0.00 & 26.94 & 0.00 & 0.00 & 8.66 & 0.00 \\
\hline Neochromadora 2A & 0.00 & 16.14 & 1.14 & 0.00 & 22.25 & 0.00 & 0.00 & 0.00 & 0.00 & 0.00 \\
\hline Elzalia 1B & 4.99 & 6.76 & 10.58 & 0.00 & 2.12 & 0.00 & 0.00 & 0.00 & 0.00 & 14.29 \\
\hline Theristus 1B & 0.00 & 0.00 & 0.00 & 0.00 & 2.12 & 0.00 & 0.00 & 34.61 & 0.00 & 0.00 \\
\hline Halichoanolaimus 2B & 0.00 & 0.00 & 0.00 & 0.00 & 0.00 & 0.00 & 0.00 & 0.00 & 23.89 & 0.00 \\
\hline Longicyatholaimus 2A & 0.00 & 0.00 & 21.37 & 0.00 & 0.00 & 0.00 & 0.00 & 0.00 & 0.00 & 0.00 \\
\hline Linhomoeus 2A & 0.00 & 0.00 & 0.00 & 0.00 & 0.00 & 0.00 & 0.00 & 0.00 & 18.27 & 0.00 \\
\hline Thalassironus 2A & 0.00 & 0.00 & 0.00 & 0.00 & 0.00 & 0.00 & 0.00 & 0.00 & 18.27 & 0.00 \\
\hline Eumorpholaimus 1B & 0.00 & 0.00 & 17.82 & 0.00 & 0.00 & 0.00 & 0.00 & 0.00 & 0.00 & 0.00 \\
\hline Metalinhomoeus 1B & 0.00 & 0.00 & 0.00 & 0.00 & 0.00 & 0.00 & 0.00 & 0.00 & 17.60 & 0.00 \\
\hline Wieseria 1A & 0.00 & 0.00 & 0.00 & 0.00 & 0.00 & 0.00 & 0.00 & 0.00 & 0.00 & 14.23 \\
\hline Pierrickia 1A & 0.00 & 0.00 & 0.00 & 0.00 & 0.00 & 0.00 & 12.25 & 0.00 & 0.00 & 0.00 \\
\hline Southerniella 1B & 0.00 & 0.00 & 0.00 & 0.00 & 0.00 & 0.00 & 0.00 & 0.00 & 8.66 & 0.00 \\
\hline Polygastrophora 2B & 0.00 & 0.00 & 7.56 & 0.00 & 0.00 & 0.00 & 0.00 & 0.00 & 0.00 & 0.00 \\
\hline Desmolaimus 1B & 0.00 & 0.00 & 0.00 & 0.00 & 0.00 & 0.00 & 0.00 & 0.00 & 2.67 & 0.00 \\
\hline Eleutherolaimus 1B & 0.00 & 0.00 & 0.00 & 0.00 & 0.00 & 0.00 & 0.00 & 0.00 & 2.67 & 0.00 \\
\hline Paracanthonchus 2A & 0.00 & 0.00 & 1.88 & 0.00 & 0.00 & 0.00 & 0.00 & 0.00 & 0.00 & 0.00 \\
\hline Not identified & 0.00 & 0.00 & 21.37 & 3.31 & 0.00 & 8.71 & 0.00 & 25.25 & 17.31 & 42.87 \\
\hline Total & 320.08 & 802.56 & 1365.44 & 1256.36 & 1417.20 & 3441.09 & 2084.92 & 2749.48 & 1754.00 & 1783.44 \\
\hline
\end{tabular}


Table 3. Results of two-way ANOVA and two-way PERMANOVA for descriptors of nematode assemblages using seasons and stations as factors in the proximity of a shrimp farm in the Curuçá estuary. $\mathrm{S}=$ genera richness, $\mathrm{N}=$ density, $\mathrm{D}=$ diversity, Mult $($ nema $)=$ multivariate structure of nematode assemblage. Asterisks represent significant differences $(p<0.05)$.

\begin{tabular}{|c|c|c|c|c|c|}
\hline ANOVA & Source & DF & MS & $\mathrm{F}$ & $P$ \\
\hline \multirow{3}{*}{ S } & Seasons & 1 & 0.58 & 6.39 & $0.024 *$ \\
\hline & Stations & 4 & 0.41 & 4.50 & $0.007 *$ \\
\hline & Seasons x Stations & 4 & 0.45 & 4.97 & $0.004 *$ \\
\hline \multirow{5}{*}{$\mathrm{N}$} & Error & 25 & 0.09 & & \\
\hline & Seasons & 1 & 10.16 & 13.67 & $0.001 *$ \\
\hline & Stations & 4 & 0.48 & 0.65 & 0.631 \\
\hline & Seasons x Stations & 4 & 2.20 & 2.96 & $0.040^{*}$ \\
\hline & Error & 25 & 0.74 & & \\
\hline \multirow{4}{*}{$\mathrm{D}$} & Seasons & 1 & 0.10 & 9.69 & $0.005^{*}$ \\
\hline & Stations & 4 & 0.03 & 2.56 & 0.063 \\
\hline & Seasons x Stations & 4 & 0.02 & 1.87 & 0.147 \\
\hline & Error & 25 & 0.01 & & \\
\hline \multicolumn{6}{|c|}{ PERMANOVA } \\
\hline \multirow{5}{*}{ Mult (nema) } & Source & $\mathrm{DF}$ & MS & Pseudo-F & $\mathrm{P}($ perm $)$ \\
\hline & Seasons & 1 & 8315.10 & 8.57 & $0.001 *$ \\
\hline & Stations & 4 & 2951 & 3.04 & $0.001 *$ \\
\hline & Seasons x Stations & 4 & 3134.50 & 3.23 & $0.001 *$ \\
\hline & Error & 25 & 969.91 & & \\
\hline
\end{tabular}

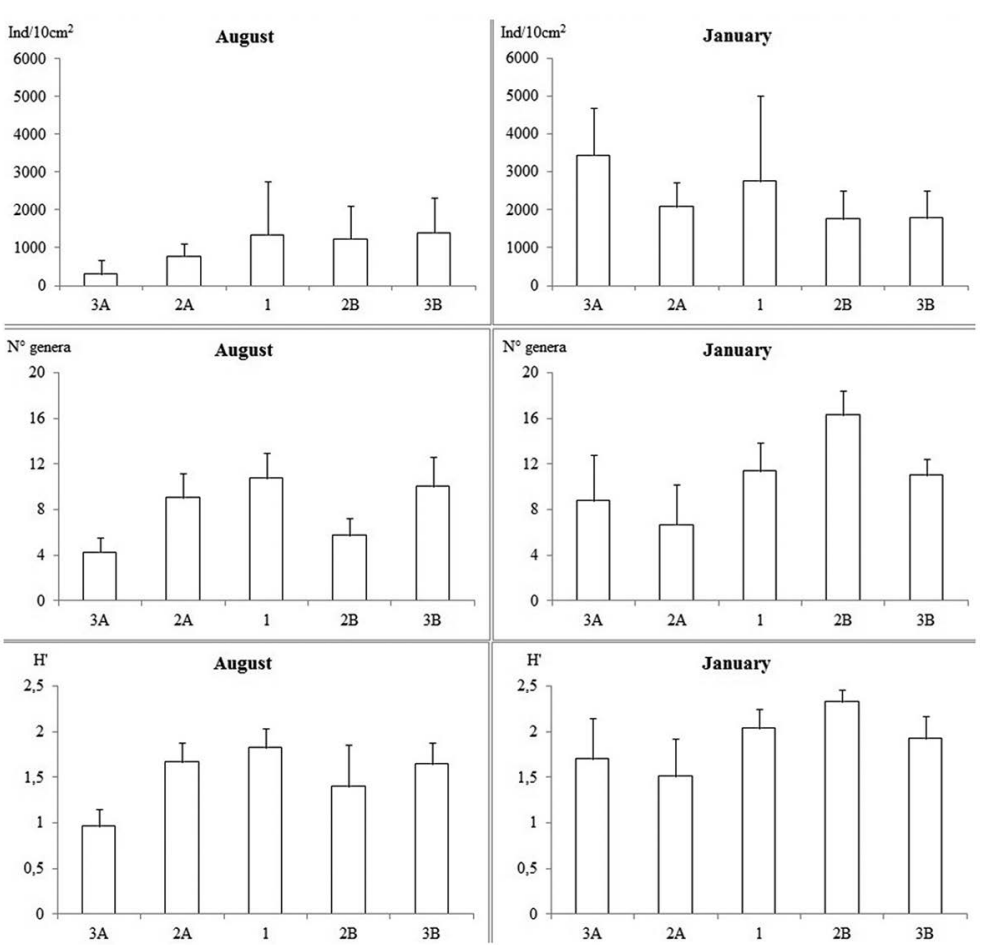

Figure 2. Mean $( \pm \mathrm{SD})$ values of density (ind. $\left./ 10 \mathrm{~cm}^{2}\right)$, genera richness and diversity $\left(\mathrm{H}^{\prime}\right)$ of Nematoda in the proximity of a shrimp farm in the Curuçá estuary. 
Table 4. Results of the paired tests for descriptors of nematode assemblages using seasons and stations as factors in the proximity of a shrimp farm in the Curuçá estuary. S: genera richness, $\mathrm{N}=$ density, $\mathrm{D}=$ diversity, Mult(nema) = multivariate structure of nematode assemblage. $\mathrm{ns}=$ not significant; * significant differences $(p<0.05)$

\begin{tabular}{|c|c|c|c|c|c|c|c|c|c|c|c|}
\hline \multirow[t]{2}{*}{$\mathrm{S}$} & \multicolumn{5}{|c|}{ August } & \multicolumn{6}{|c|}{ January } \\
\hline & 1 & $2 \mathrm{~A}$ & $2 \mathrm{~B}$ & $3 \mathrm{~A}$ & $3 B$ & & 1 & $2 \mathrm{~A}$ & $2 \mathrm{~B}$ & $3 \mathrm{~A}$ & $3 B$ \\
\hline 1 & - & & & & & 1 & - & & & & \\
\hline $2 \mathrm{~A}$ & ns & - & & & & $2 \mathrm{~A}$ & $\mathrm{~ns}$ & - & & & \\
\hline $2 \mathrm{~B}$ & ns & $\mathrm{ns}$ & - & & & $2 \mathrm{~B}$ & $\mathrm{~ns}$ & $*$ & - & & \\
\hline $3 \mathrm{~A}$ & $*$ & $\mathrm{~ns}$ & $\mathrm{~ns}$ & - & & $3 \mathrm{~A}$ & $\mathrm{~ns}$ & ns & ns & - & \\
\hline $3 \mathrm{~B}$ & ns & $\mathrm{ns}$ & ns & ns & - & $3 \mathrm{~B}$ & ns & ns & ns & ns & - \\
\hline \multirow[t]{2}{*}{$\mathrm{N}$} & \multicolumn{5}{|c|}{ August } & \multicolumn{6}{|c|}{ January } \\
\hline & 1 & $2 \mathrm{~A}$ & $2 \mathrm{~B}$ & $3 \mathrm{~A}$ & $3 \mathrm{~B}$ & & 1 & $2 \mathrm{~A}$ & $2 \mathrm{~B}$ & $3 \mathrm{~A}$ & $3 B$ \\
\hline 1 & - & & & & & 1 & - & & & & \\
\hline $2 \mathrm{~A}$ & ns & - & & & & $2 \mathrm{~A}$ & $\mathrm{~ns}$ & - & & & \\
\hline $2 \mathrm{~B}$ & ns & $\mathrm{ns}$ & - & & & $2 \mathrm{~B}$ & $\mathrm{~ns}$ & $\mathrm{~ns}$ & - & & \\
\hline $3 \mathrm{~A}$ & ns & ns & ns & - & & $3 \mathrm{~A}$ & $\mathrm{~ns}$ & $\mathrm{~ns}$ & ns & - & \\
\hline $3 \mathrm{~B}$ & ns & ns & $\mathrm{ns}$ & ns & - & $3 \mathrm{~B}$ & $\mathrm{~ns}$ & $\mathrm{~ns}$ & ns & ns & - \\
\hline \multirow[t]{2}{*}{ D } & \multicolumn{5}{|c|}{ August } & \multicolumn{6}{|c|}{ January } \\
\hline & 1 & $2 \mathrm{~A}$ & $2 \mathrm{~B}$ & $3 \mathrm{~A}$ & $3 \mathrm{~B}$ & & 1 & $2 \mathrm{~A}$ & $2 \mathrm{~B}$ & $3 \mathrm{~A}$ & $3 B$ \\
\hline 1 & - & & & & & 1 & - & & & & \\
\hline $2 \mathrm{~A}$ & ns & - & & & & $2 \mathrm{~A}$ & $\mathrm{~ns}$ & - & & & \\
\hline $2 \mathrm{~B}$ & ns & ns & - & & & $2 \mathrm{~B}$ & $\mathrm{~ns}$ & $\mathrm{~ns}$ & - & & \\
\hline $3 \mathrm{~A}$ & ns & $\mathrm{ns}$ & $\mathrm{ns}$ & - & & $3 \mathrm{~A}$ & $\mathrm{~ns}$ & $\mathrm{~ns}$ & ns & - & \\
\hline $3 \mathrm{~B}$ & $\mathrm{~ns}$ & $\mathrm{~ns}$ & $\mathrm{~ns}$ & $\mathrm{~ns}$ & - & $3 B$ & $\mathrm{~ns}$ & $\mathrm{~ns}$ & ns & ns & - \\
\hline \multirow[t]{2}{*}{$\begin{array}{l}\text { PERMANOVA - } \\
\text { Mult (nema) }\end{array}$} & \multicolumn{5}{|c|}{ August } & \multicolumn{6}{|c|}{ January } \\
\hline & 1 & $2 \mathrm{~A}$ & $2 B$ & $3 \mathrm{~A}$ & $3 B$ & & 1 & $2 \mathrm{~A}$ & $2 \mathrm{~B}$ & $3 \mathrm{~A}$ & $3 B$ \\
\hline 1 & - & & & & & 1 & - & & & & \\
\hline $2 \mathrm{~A}$ & ns & - & & & & $2 \mathrm{~A}$ & $\mathrm{~ns}$ & - & & & \\
\hline $2 \mathrm{~B}$ & $*$ & $\mathrm{~ns}$ & - & & & $2 \mathrm{~B}$ & $*$ & $*$ & - & & \\
\hline $3 \mathrm{~A}$ & $*$ & $*$ & * & - & & $3 \mathrm{~A}$ & $*$ & $\mathrm{~ns}$ & $*$ & - & \\
\hline $3 B$ & ns & $\mathrm{ns}$ & ns & $\mathrm{ns}$ & - & $3 \mathrm{~B}$ & $\mathrm{~ns}$ & $\mathrm{~ns}$ & $\mathrm{~ns}$ & $\mathrm{~ns}$ & - \\
\hline
\end{tabular}

ind $/ 10 \mathrm{~cm}^{2}$, respectively (Figure 2). In August the highest densities were recorded at the central station (1) and the stations located downstream (B). In January the highest densities were recorded at the central station and those located upstream (A). Significant differences were found for abundances when comparing seasons and interactions between seasons and stations (Table 3). The differences found for abundances are due to the much higher densities in January, with values never less than those found in August. Diversity varied significantly only between seasons with values higher during the rainy season than during the dry season, the exception being station $2 \mathrm{~A}$ (Table 3, Figure
2). In a general overview of the stations, those with highest genera richness were also the stations with highest diversity, but no other clear patterns were observed.

It is possible, on the MDS plot, to observe a distinction between the dry and rainy seasons' samples (the dry season's being on the right side of the plot), but not between different stations'. However, a slight distinction between stations 1 and 2, on the one hand, and station 3 , on the other, can be seen during the rainy season (Figure 3). The nematode assemblage structure varied significantly between seasons, stations and interactions between seasons and stations (Table 3). 


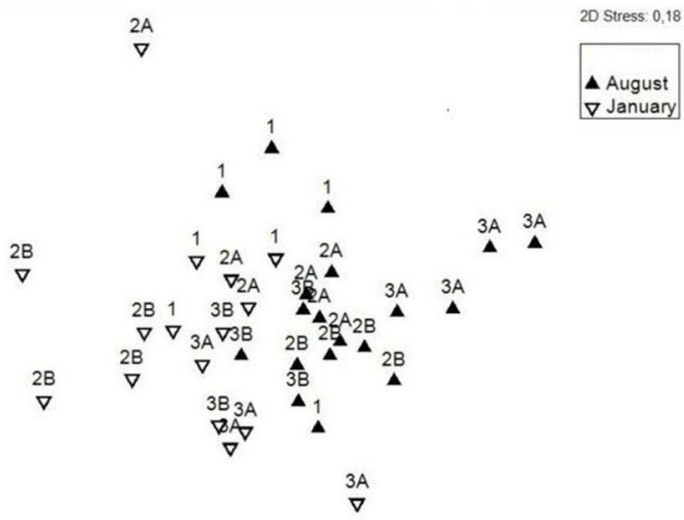

Figure 3. Non-metric Multidimensional Scaling plot of samples in the proximity of a shrimp farm in the Curuçá estuary.

\section{DISCUSSION}

In the present study the main differences for nematodes were found between seasons, when higher abundances, richness and diversity were found for the rainy month (January). Although differences were found for nematodes, the sediment parameters investigated (organic matter, nitrogen and phosphorus) did not present a significant variation between seasons. Concerning stations, no clear differences were observed either for nematodes or sediment characteristics. These results give us an indication as to the situation of the Curuçá estuary in terms of nutrient enrichment and its possible effects on nematodes.

One of the indicators of environmental modification is eutrophication, which can be defined as water nutrient enrichment, especially by nitrogen and/or phosphorus and organic matter. This nutrient enrichment can cause disturbance to the structure, function and stability of organisms present in the water and the quality of the water itself (ANDERSEN et al., 2006). In Curuçá estuary the concentrations of organic matter (always less than $0.48 \%$ ) were low as compared to those of other localities, either impacted (e.g. more than 1.6\% in MAHMOUDI et al. 2008 and around 3\% in NETTO and VALGAS, 2010, both close to mussel farms) or non-impacted (e.g. more than $3 \%$ in NETTO and GALLUCCI, 2003 in Ratones river estuary, South Brazil and from 0.51 to $14.24 \%$ in VASCONCELOS et al., 2004 in Rio Formoso estuary, Northeast Brazil). Values of nitrogen (from 0.14 to $0.19 \%$ ) were within the range registered for other estuarine areas (e.g. 0.02 $0.16 \%$ in JAPTAP, 1987 in Goa, India and $0.05-0.8 \%$ in MUROLO et al., 2006 in the Siri estuary, Northeast Brazil). As for the values of phosphorus (less than $39 \mathrm{mg} / \mathrm{dm}^{3}$ ), they were within the range as compared with those of some other estuarine areas $\left(1-98 \mathrm{mg} / \mathrm{dm}^{3}\right.$ in MUROLO et al., 2006 in the Siri estuary, Northeast Brazil) but much lower than those of some other estuarine localities $\left(220-540 \mathrm{mg} / \mathrm{dm}^{3}\right.$ in BOTO and WELLINGTON, 1984 in Australia). These comparisons led us to conclude that although Curuçá estuary shows some signs of eutrophication, it is not yet intense. The vigorous local hydrodynamics, consequence of strong currents and macrotidal regime, may be responsible for the suspension of organic matter and nutrients and consequent reduction of their concentrations in the sediment. Probably, the higher values of all the environmental parameters at the downstream stations as compared to the upstream ones are also a direct consequence of the local hydrodynamics.

The nematode abundances found in the Curuçá estuary $\left(320.08-3441.09 \mathrm{ind} / 10 \mathrm{~cm}^{2}\right)$ are within the range registered in other Brazilian estuaries: $598-2844.4$ ind $/ 10 \mathrm{~cm}^{2}$ in Santa Cruz Channel, Northeast Brazil (ALMEIDA; FONSECA-GENEVOIS, 1999); 36 - 3339 ind $/ 10 \mathrm{~cm}^{2}$ in Pina Basin, Northeast Brazil (SOMERFIELD et al., 2003); $972.4-6007.1 \mathrm{ind} / 10 \mathrm{~cm}^{2}$ in Rio Formoso, Northeast Brazil (VASCONCELOS et al., 2004) and 133.1 - $719.2 \mathrm{ind} / 10 \mathrm{~cm}^{2}$ in Tramandaí-Armazém, South Brazil (KAPUSTA et al., 2005). The abundances showed a strong temporal pattern with significantly higher values in the rainy season (January). This result is different from those given by other studies conducted in tropical estuaries that found higher densities during the dry season (ALMEIDA; FONSECA-GENEVOIS, 1999) or did not find any clear pattern (GOMES et al., 2002; SANTOS et al., 2007). ISAAC and BARTHEM (1995) state that rain is the main factor responsible for biological changes in the Amazonian region. During periods of high precipitation abrupt changes can occur in salinity values measured in estuaries. It seems that the nematodes in Curuçá were favored by the lower salinities during the rainy season, presenting not only higher abundances but also significantly richer and more diverse assemblages. Higher abundances and richness during the rainy season had already been observed by PAULA et al. (2006) when studying the meiobenthos community in the same samples. The authors saw that nematodes were the dominant meiobenthic taxon and in our study we confirmed that the nematode assemblage considered at low taxonomic level maintained the same pattern as the meiobenthos community.

As compared to investigations into metallic or other pollution sources, studies of the impact of farming on meiobenthos are still rare and the majority of them report experiments or sampling strategies developed over a short 
period (generally not more than some weeks). Few studies consider longer periods (such as months), therefore the possible seasonal variations or long-term effects of farming are not usually investigated. In areas such as the Amazonian region seasonal variations are specially important because of the strong variation in hydrodynamics, which could be responsible for the re-distribution of farming discharges. MIRTO et al. (2002) and MIRTO et al. (2012) are among the few studies that have investigated the effects of a Mediterranean fish farm on nematodes for longer periods, i.e., 7 and 10 months, respectively. These authors found strong differences between controls and impacted sites, but not between months. In Curuçá the pattern of nematode variation was clearly seasonal and did not vary between locations. This result suggests that in areas with vigorous hydrodynamics, studies of the effect of any impact should be interpreted with caution.

The genera Terschellingia and Sabatieria presented, respectively, the highest and most consistent abundances in Curuçá estuary. Both genera are frequently cited as among the most abundant nematodes in Brazilian estuaries (e.g. FONSECA; NETTO, 2006; KAPUSTA et al., 2006) and also in studies involving farming effects. NETTO and VALGAS (2010) investigating the responses of nematode assemblages to the effects of intensive mussel farming in a South Brazilian shallow embayment (Bay of Santa Catarina Island) declared Terschellingia to be the most abundant genus at mussel farm sites and found Sabatieria to be among the most abundant genera at both mussel farm and control sites. NETTO and MEURER (2007) studying the shrimp farm impact in benthic communities at another South Brazilian site (Laguna Estuarine System) also reported Terschellingia and Sabatieria as among the most abundant nematode genera. Considering the whole nematode assemblage of Curuçá, predator/omnivorous genera (type 2B) such as Gomphionema, Metachromadora and Hypodontolaimus seemed to be favored by the rainy season, with increases in their densities. Probably the higher abundances and richness of meiobenthic groups and nematodes, which can be feeding resources for genera of type $2 \mathrm{~B}$, contributed to this result. Considering nematode assemblages, clear differences were again detected as between seasons, though not between stations. The most abundant genera Terschellingia, Sabatieria, Daptonema, Gomphionema, Ptycholaimellus and Metachromadora were almost constantly present at all stations. Their main variation related to their abundances between seasons. This result indicates that the shrimp farm investigated in Curuçá also had no effect on the main nematode genera, as has already been reported for total nematode abundance.

Studies that have used nematode abundance as one of the indicators of farming impacts on meiobenthos have detected different responses. Studying the effect of mussel culture on nematodes, CASTEL et al. (1989), GUELORGET et al. (1994) and MAHMOUDI et al. (2008) found an increase in densities; MIRTO et al. (2000) and NETTO and VALGAS (2007) reported a decrease in abundances and DANOVARO et al. (2004) and PINTO et al. (2007) found no significant changes. Concerning the effect of shrimp farm impacts, PATRONA et al. (2012) found a decrease in meiobenthos abundance and NETTO and MEURER (2007) registered a decrease in nematode abundance but only after the postcultivation period. In Curuçá the response of nematodes to shrimp farm discharge was not clear. No decreasing pattern was observed in abundance, genera richness or diversity from the more distant to the central station (station 1). On the contrary, the central station presented the second highest abundances in both seasons and as regards genera richness and diversity the central station presented the highest values during the dry season and the second highest values during the rainy season. MAHMOUDI et al. (2008) and NETTO and VALGAS (2010) suggest that low hydrodynamics and/ or microtidal regime would, respectively, limit the dispersal of biodeposits of mussel farms in a Mediterranean lagoon or a South Brazilian shallow embayment. On the basis of this idea we suppose that the vigorous local hydrodynamics in Curuçá might be responsible for the rapid dispersal of the local shrimp farm residues as a result of which there is no clear change in nematode assemblages at the sampling sites close to the shrimp farm.

Another possibility is that the shrimp farm in Curuçá, which was established only five years before our study, had not yet had time to cause any real impact, also perhaps because the area occupied by it (55ha with production of 60 to 180 tons per year according to MARTINELLI and FREITAS-JUNIOR, 2007) is small compared to those of farms monitored in similar studies where clear changes in nematode assemblages have been found: e.g. 400 tons per year of production in a fish farm studied by MIRTO et al. (2002), 1000ha of shrimp farm studied by NETTO and MEURER (2007) and 20ha of mussel farm with production of 1500 tons per year studied by NETTO and VALGAS (2010). As in our study, PINTO et al. (2007) when studying the impact of a mussel farm in South Brazil with lower production (20 to 24 tons per year) also found no significant changes in meiobenthos community. The 
authors recommended that studies should be undertaken with refined taxonomy in order to obtain a more precise response. OLAFSSON et al. (1995) studying the effect of seaweed farming on meiobenthos in a tropical lagoon of Zanzibar could compare the response of nematodes at major taxon (pylum) and minor (genera/species) levels and were able to find significant alterations in nematode assemblages only when using a refined taxonomy. In our study we would also have been able to verify whether with a refined taxonomy a different response could have been obtained. PAULA et al. (2006) in a previous study analyzing the meiobenthos community in the same samples as we used in our study were also unable to detect significant differences. The use of a refined taxonomy is not, therefore, the only question deserving of consideration in future studies.

Global demand for seafood continues to rise despite most wild animal resources being at their maximum level of sustainable exploitation (DE SILVA, 2012). At the beginning of this century the prediction was that by 2030 more than $50 \%$ of fisheries production would need to come from aquaculture in view of human population growth, the continuing demand for seafood, and static or declining fish harvests (FAO, 2000). This percentage was, however, attained earlier than had been expected and in 2011 aquaculture already accounted for nearly 50\% of global fish consumption, and the activity was reputed to be the fastest growing primary production sector, averaging an annual growth rate of nearly 7\% (FAO, 2011). Meeting the food demand for a growing population is a major issue confronting us globally, with continuing population and consumption growth expected to increase for at least the next 40 years (GODFRAY et al., 2010). Assuring food security or responding to the challenge of feeding 9 billion people by 2050 has to be achieved in a climate of increasing competition for land, water and energy and, as is also important, with a reduced impact of the food system on the environment (GODFRAY et al., 2010). Aquaculture is in a phase of adjustment, attempting to embrace practices that are conceivably more environmentally friendly and sustainable (DE SILVA, 2012), we are, therefore, in time to unite this line of thinking with continuous and more efficient environmental monitoring. In environments such as Amazonian mangrove swamps where shrimp farming is still at an early stage it is especially important to study aquaculture impacts because the farms can then adapt their practices from the beginning and consequently reduce local degradation. We recommend that in future studies of farming impact should cover a combination of factors beyond the physical/chemical parameters or taxonomical refinement which should also be taken into account, among them being: the time of establishment of the farm, the area occupied by it and its production. Furthermore, we believe that nematodes are a useful tool in evaluating aquaculture impacts due to the relatively easy sampling involved and because they are organisms at the base of marine food chains.

\section{ACKNOWLEDGEMENTS}

The sampling was conducted within the project "Use and appropriation of coastal zone resources Millenium Institute" and was funded by CNPq (Brazilian Research Council). The authors wish to express their gratitude to Petrobras (Brazilian Petroleum Company) for research fellowships and Dr. José Souto Rosa-Filho for the opportunity to work with these samples and for his suggestions regarding a previous version of the manuscript. We are also grateful to two anonymous referees and the editor for improving the previous version of this manuscript.

\section{REFERENCES}

ABCC - Associação Brasileira dos Criadores de Camarões. 2013. Available at: < http://www.abccam.com.br>. Accessed 19 July 2013.

ALMEIDA, Z. S.; FONSECA-GENEVOIS, V. Análise quali-quantitativa da meiofauna na região de Itapissuma - PE. Pesq. Foco, v. 7, n. 9, p. 115-137, 1999.

ANDERSEN, J. H.; SCHLÜTER, L.; AERTEBJERG, G. Coastal eutrophication: recent developments in definitions and implications for monitoring strategies. J. Plankt. Res., v. 28, n. 7, p. 117-143, 2006.

BARRAZA-GUARDADO, R. H.; ARREOLA-LIZÁRRAGA, J. A.; LÓPEZ-TORRES, M. A.; CASILLAS-HERNÁNDEZ, R.; MIRANDA-BAEZA, A.; MAGALLÓN-BARRAJAS, F.; IBARRA-GÁMEZ, C. Effluents of shrimp farms and its influence on the coastal ecosystems of Bahía de Kino, Mexico. Sci. World J., v. 2013, 8 p., 2013.

BERLANGA-ROBLES, C. A.; RUIZ-LUNA, A.; HERNÁNDEZ-GUZMÁN, R. Impact of Shrimp Farming on Mangrove Forest and Other Coastal Wetlands: the case of Mexico. In: SLADONJA, B. (Ed.). Aquaculture and the Environment - A Shared Destiny. Rijeka: Intech, 2011. p. 1-15.

BONGERS, T.; FERRIS, H. Nematode community structure as a bioindicator in environmental monitoring. Trends Ecol. Evol., v. 16, n. 6, p. 224-228, 1999.

BOTO, K. G.; WELLINGTON, J. T. Soil characteristics and nutrient status in northern Australian mangrove forests. Estuaries, v. 7, p. 61-69, 1984.

BOYD, C. E. Farm effluent during draining for harvest. Global Aquacul., v. 3, p. 26-27, 2000. 
CASTEL, J.; LABOURG, P. J.; ESCARAVAGE, V.; AUBY, I.; GARCIA, M. E. Influence of seagrass beds and oyster parks on the abundance and biomass patterns of meio- and macrobenthos in tidal flats. Estuar. Coast. Shelf Sci., v. 28, n. 1, p. 71-85, 1989.

CONSTANZO, S. D.; O’DONOHUE, M. J.; DENNISON, W. C. Assessing the influence and distribution of shrimp pond effluent in a tidal mangrove creek in north-east Australia. Mar. Pollut. Bull., v. 48, n. 5/6, p. 514-525, 2004.

COULL, B. C.; CHANDLER, G. T. Pollution and meiofauna: field, laboratory and mesocosm studies. Oceanogr. Mar. Biol. Ann. Rev., v. 30, p. 191-271, 1992.

DANOVARO, R.; FABIANO, M.; VINCX, M. Meiofauna response to the Agip Abruzzo oil spill in subtidal sediments of the Ligurian Sea. Mar. Pollut. Bull., v. 30, p. 133-145, 1995.

DANOVARO, R.; GAMBI, C.; LUNA, G. M.; MIRTO, S. Sustainable impact of mussel farming in the Adriatic Sea (Mediterranean Sea): Evidence from biochemical, microbial and meiofaunal indicators. Mar. Pollut. Bull., v. 49, n. 4, p. 325333, 2004.

DE GRISSE, A. T. Redescription ou modification de quelques techniques utilisés dans l'étude des nématodes phytoparasitaires. Mededel. Rijks. Landbouw. Gent., v. 34, p. 351-369, 1969.

DE SILVA, S. S. Aquaculture: a newly emergent food production sector - and perspectives of its impacts on biodiversity and conservation. Biodivers. Conserv., v. 21, n. 12, p. 3187-3220, 2012.

DEBENAY, J. P.; DELLA PATRONA, L.; HERBLAND, A.; GOGUENHEIM, H. The impact of easily oxidized material $(E O M)$ on the meiobenthos: Foraminifera abnormalities in shrimp ponds of New Caledonia; implications for environment and paleoenvironment survey. Mar. Pollut. Bull., v. 59, p. 323-335, 2009 .

ELMGREN, R. Methods of sampling sublittoral soft bottom meiofauna. Oikos, v. 15, p. 112-120, 1973.

FAO. The state of world fisheries and aquaculture. Food and Agriculture Organization. Rome, 2000.

FAO. World aquaculture 2010. FAO Fisheries and Aquaculture Technical Paper. 500/1. Rome, 2011.

FERREIRA, R. C.; NASCIMENTO-JUNIOR, A. B.; SANTOS, P. J. P.; BOTTER-CARVALHO, M. L.; PINTO, T. K. Responses of estuarine nematodes to an increase in nutrient supply: an in situ continuous addition experiment. Mar. Pollut. Bull., v. 90, n. 1/2, p. 115-120, 2015.

FLAMBOT, F. C. Aqüicultura: indicadores de salinidade da água na microrregião do Salgado. Belém: Banco da Amazônia, 1988. $43 \mathrm{p}$

FOLKE, C.; KAUTSKY, N. Aquaculture with its environment prospects for sustainability. Ocean. Coast. Manag., v. 17, p. 5-24, 1992.

FONSECA, G.; NETTO, S. A. Shallow sublittoral benthic communities of the Laguna Estuarine System, South Brazil. Braz. J. Oceanog., v. 54, n. 1, p. 41-54, 2006.

GEE, J. M.; AUSTEN, M.; DE SMET, G.; FERRARO, T.; MCAVOY, A.; MOORE, S.; VAN GAUSBEKI, D.; VINCX, M.; WARWICK, R. M. Soft sediment meiofauna community responses to environmental pollution gradients in the German bight and at a drilling site off the Dutch coast. Mar. Ecol. Prog., v. 91, p. 289-302, 1992.
GIERE, O. Meiobenthology: the microscopic motile fauna in aquatic sediments. 2nd. ed. Berlin: Springer-Verlag, 2009. 527 p.

GODFRAY, H. C. J.; BEDDINGTON, J. R.; CRUETE, I. R.; HADDAD, L.; LAWRENEC, D.; MUIR, J. F.; PRETTI, J.; ROBINSON, M. S.; THOMAS, S. M.; TOULMIN, C. Food security: the challenge of feeding 9 billion people. Science, v. 327 , p. 812-817, 2010.

GOMES, C. A. A.; SANTOS, P. J. P.; ALVES, T. N. C.; ROSA-FILHO, J. S.; SOUZA-SANTOS, L. P. Variação temporal da meiofauna em área de manguezal em Itamaracá-Pernambuco. Atlantica, v. 24, n. 2, p. 35-42, 2002.

GREGO, M.; DE TROCH, M.; FORTE, J.; MALEJ, A. Main meiofauna taxa as an indicator for assesssing the spatial and seasonal impact of fish farming. Mar. Poll. Bull., v. 58, n. 8, p. $1178-1186,2009$.

GUELORGET, O.; PERTHUISOT, J. P.; LAMY, N.; LEFEBRE, A. Structure et organization de l'etang de Thau d' aprés la fauna benthique (macrofaune, meiofaune). Relations avec le confinement. Ocean. Acta, v. 17, n. 1, p. 105-114, 1994.

ISAAC, V. J.; BARTHEM, R. B. Os recursos pesqueiros da Amazônia brasileira. Bol. Mus. Para. Emílio Goeldi, Série antropologia, v. 11, n. 2, p. 295-339, 1995.

JAPTAP, T. G. Seasonal distribution of organic matter in mangrove environment of Goa. Ind. J. Mar. Sci., v. 16, p. 103-106, 1987.

KAPUSTA, S. C.; WÜRDING, N. L.; BEMBENUTI, C. E.; OZORIO, C. P. Meiofauna structure in Tramandaí-Armazém estuary (South of Brazil). Acta Limnol. Bras., v. 17, n. 4, p. 349-359, 2005.

KAPUSTA, S. C.; WURDIG, N. L.; BEMVENUTI, C. E.; PINTO, T. K. Spatial and temporal distribution of Nematoda in a subtropical estuary. Acta Limnol. Bras., v. 18, n. 2, p. 133144, 2006.

KJERFVE, B.; LACERDA, L. D. Mangroves of Brazil. In: LACERDA, L. D. (Eds.). Conservation and sustainable utilization of mangrove forest in Latin America and Africa regions. Part I - Latin America. Mangrove Ecosystem Technical Report No.2. Okinawa: International Tropical Timber Organization/International Society for Mangrove Ecosystems, 1993. p. 245-272.

LA ROSA, T.; MIRTO, S.; MAZZOLA, A.; DANOVARO, R. Differential responses of benthic microbes and meiofauna to fish-farm disturbance in coastal sediments. Environ. Poll., v. 112 , n. 3, p. 427-434, 2001.

MAHMOUDI, E.; ESSID, N.; BEYREM, H.; HEDFI, A.; BOUFAHJA, F.; AÏSSA, P.; VITIELLO, P. Mussel-farming effects on Mediterranean benthic nematode communities. Nematology, v. 10, n. 3, p. 323-333, 2008.

MARTINELLI, J. M.; FREITAS-JÚNIOR, J. R. C. Diagnóstico da carcinicultura marinha no estado do Pará. In: BARROSO, G. F.; POERSCH, L. H. S.; CAVALLI, R. O. (Eds.). Sistemas de cultivos aquicolas na zona costeira do Brasil: recursos, tecnologias, aspectos ambientais e sócio-economicos. Rio de Janeiro: Museu Nacional, 2007. p. 291-302.

MAZZOLA, A.; MIRTO, S.; DANOVARO, R. Initial fish-farm impact on meiofaunal assemblages in coastal sediments of the Western Mediterranean. Mar. Poll. Bull., v. 38, n. 12, p. 1126-1133, 1999.

MCKINNON, A. D.; TROTT, L. A.; ALONGI, D. M.; DAVIDSON, A. Water column production and nutrient characteristics in mangrove creeks receiving shrimp farm effluent. Aquac. Res., v. 33, n. 1, p. 55-73, 2002. 
MIRTO, S.; LA ROSA, T.; DANOVARO, R.; MAZZOLA, A. Microbial and meiofaunal response to intensive mussel-farm biodeposition in coastal sediments of the western Mediterranean. Mar. Pollut. Bull., v. 40, n. 3, p. 244-252, 2000.

MIRTO, S.; LA ROSA, T.; GAMBI, C.; DANOVARO, R.; MAZZOLA, A. Nematode community response to fish-farm impact in the western Mediterranean. Environ. Pollut., v. 116, n. 2, p. 203-214, 2002.

MIRTO, S.; GRISTINA, M.; SINOPOLI, M.; MARICCHIOLO, G.; GENOVESE, L.; VIZZINI, S.; MAZZOLA, A. Meiofauna as an indicator for assessing the impact of fish farming at an exposed marine site. Ecol. Indic., v. 18, p. 468-476, 2012.

MOLNAR, N.; WELSH, D. T.; MARCHAND, C.; DEBORDE, J.; MEZIANE, T. Impacts of shrimp farm effluent on water quality, benthic metabolism and $\mathrm{N}$-dynamics in a mangrove forest (New Caledonia). Estuar. Coast. Shelf Sci., v. 117, p. 12-21, 2013.

MORAES, B. C.; COSTA, J. M. N.; COSTA, A. C. L.; COSTA, M. H. Variação espacial e temporal da precipitação no estado do Pará. Acta Amaz., v. 35, n. 2, p. 207-214, 2005.

MUROLO, P. P. A.; CARVALHO, P. V. V. C.; CARVALHO, M. L. B.; SOUZA-SANTOS, L. P.; SANTOS, P. J. P. Spatio-temporal variations of microphytobenthos in the Botafogo and Siri estuaries (Northeast - Brazil). Braz. J. Oceanog., v. 54 , n. 1, p. 19-30, 2006.

MURPHY, J.; RILEY, J. P. A single-solution method for the determination of phosphate in seawaters. J. Mar. Biol. Assoc. U. K., v. 37, n. 1, p. 9-14, 1958.

NAYLOR, R. L.; GOLDBURG, R. J.; PRIMAVERA, J. H.; KAUTSKY, N.; BEVERIDGE, M. C. M.; CLAY, J.; FOLKE, C.; LUBCHENCO, J.; MOONEY, H.; TROELL, M. Effect of aquaculture on world fish supplies. Nature, v. 405, p. 10171024, 2000.

NETTO, S. A.; GALLUCCI, F. Meiofauna and macrofauna communities in a mangrove from the Island of Santa Catarina, South Brazil. Hydrobiologia, v. 505, n. 1, p. 159-170, 2003.

NETTO, S. A.; MEURER, A. Z. Influência de efluentes de cultivo de camarão na estrutura das comunidades bênticas do sistema estuarino de Laguna (SC, Brasil). In: BARROSO, G. F.; POERSCH, L. H. S.; CAVALLI, R. O. (Eds.). Sistemas de cultivos aquicolas na zona costeira do Brasil: recursos, tecnologias, aspectos ambientais e sócio-econômicos. Rio de Janeiro: Museu Nacional, 2007a. p. 129-138.

NETTO, S. A.; VALGAS, I. Efeitos do cultivo de mexilhões sobre a estrutura da meiofauna In: BARROSO, G. F.; POERSCH, L. H. S.; CAVALLI, R. O. (Eds.). Sistemas de cultivos aquicolas na zona costeira do Brasil: recursos, tecnologias, aspectos ambientais e sócio-economicos. Rio de Janeiro: Museu Nacional, 2007b. p. 119-128.

NETTO, S. A.; VALGAS, I. The response of nematode assemblages to intensive mussel farming in coastal sediments (Southern Brazil). Environ. Assess. Manag., v. 162, n. 1, p. 81-93, 2010 .

NETTO, S. A., GALLUCCI, F.; FONSECA, G. Deep-sea meiofauna response to synthetic-based drilling mud discharge off SE Brazil. Deep Sea Res. Part II Top. Stud. Oceanogr., v. 56, n. 1, p. 41-49, 2009.

ÓlAFSSON, E.; JOHNSTONE, R. W.; NDARO, S. G. M. Effects of intensive seaweed farming on the meiobenthos in a tropical lagoon. J. Exp. Mar. Biol. Ecol., v. 191, n. 1, p. 101-117, 1995.
PÁEZ-OSUNA, F. The environmental impact of shrimp aquaculture: a global perspective. Environ. Pollut., v. 112, n. 2, p. 229-231, 2001.

PAQUOTTE, P.; CHIM, L.; MARTIN, J. L. M.; LEMOS, E.; STERN, M.; TOSTA, G. Intensive culture of shrimp Penaeus vannamei in floating cages: zootechnical, economic and environmental aspects. Aquaculture, v. 164, p. 151-166, 1998.

PATRONA, L. D.; BIANCHELLI, S.; BELIAEFF, B.; POSCEDDU, A. Meiobenthos in earthen ponds used for semi-intensive shrimp farming (New Caledonia, South Pacific). Chem. Ecol., v. 28, n. 6, p. 506-523, 2012.

PAULA, J. H. C.; ROSA-FILHO, J. S.; SOUZA, A. L. B.; AVIZ, D. A meiofauna como indicadora de impactos na carcinocultura no estuário de Curuçá (PA). Bol. Lab. Hidrobiol., v. 19, p. 61-72, 2006.

PEREIRA, C. T. C.; GIARRIZZO, T.; JESUS, A. J. S.; MARTINELLI, J. M. Caracterização do efluente de cultivo de Litopenaeus vannamei no estuário de Curuçá (PA). In: BARROSO, G. F.; POERSCH, L. H. S.; CAVALLI, R. O. (Eds.). Sistemas de cultivos aquícolas na zona costeira do Brasil: recursos, tecnologia, aspectos ambientais e sócio-econômicos. Rio de Janeiro: Museu Nacional, 2007. p. 291-302.

PINTO, T. K.; BOINA, C. D.; VIEIRA, S. D. M. A. Influência do cultivo de moluscos na comunidade bentônica: meiobenthos. In: BARROSO, G. F.; POERSCH, L. H. S.; CAVALLI, R. O. (Eds.). Sistemas de cultivos aquicolas na zona costeira do Brasil: recursos, tecnologias, aspectos ambientais e sócio-economicos. Rio de Janeiro: Museu Nacional, 2007. p. 235-241.

PRIMAVERA, J. H. Socio-economic impacts of shrimp culture. Aquac. Res., v. 28, n. 10, p. 815-827, 1997.

RIERA, R.; MONTERROSO, O.; RODRIGUEZ, M.; RAMOS, E.; SACRAMENTO, A. Six-year study of meiofauna dynamics in fish farms in Tenerife (Canary Islands, NE Atlantic Ocean). Aquat. Ecol., v. 45, n. 2, p. 221-229, 2011.

RIERA, R.; SANCHES-JEREZ, P.; RODRÍGUEZ, M.; MONTERROSO, O.; RAMOS, E. Long-term monitoring of fish farms: application of Nematode/Copepod index to oligotrophic conditions. Mar. Pollut. Bull. v. 64, n. 4, p. 844-850, 2012.

ROCHA, I. P. Shrimp farming in Brazil: burgeoning industry recovering, future holds potential. Global Aquac. Advoc., v. 13, n. 5 , p. $43-45,2010$

RODRIGUEZ-GALLEGO, L.; MEERHOFF, E.; POERSCH, L.; AUBRIOT, L.; FAGETTI, C.; VITANCURT, J.; CONDE, D. Establishing limits to aquaculture in a protected coastal lagoon: Impact of Farfantepenaeus paulensis pens on water quality, sediment and benthic biota. Aquaculture, v. 277, n. 1/2, p. 30-38, 2008.

SANTOS, P. J. P. 1999. O meiobentos da Costa Brasileira: padrões de diversidade, de densidade e de dominância. Simpósio sobre Bentos Costeiros. XII Encontro de Zoologia do Nordeste: 91-100.

SANTOS, P. J. P.; CARVALHO, P. V. V. C.; MUROLO, P. P. A.; SILVA, A. P. C.; VALENÇA, A. P. M. C.; NASCIMENTO-JÚNIOR, A. B.; VASCONCELOS, D. M.; SOUZA-SANTOS, L. P.; BOTTER-CARVALHO, M. C.; TRINDADE, R. L.; ALVES, T. N. C.; FONSECA-GENEVOIS, V.; VENEKEY, V. A comunidade bentônica na avaliação da qualidade ambiental de uma área estuarina influenciada pela carcinocultura. In: BARROSO, G. F.; POERSCH, L. H. S.; CAVALLI, R. O. (Eds.). Sistemas de cultivos aquicolas na zona costeira do Brasil: recursos, tecnologias, aspectos ambientais e sócio-economicos. Rio de Janeiro: Museu Nacional, 2007. p. 273-290. 
SANTOS, P. J. P.; BOTTER-CARVALHO, M. L.; NASCIMENTO-JÚNIOR, A. B.; MARINHO, R. G. C.; CARVALHO, P. V. V. C.; VALENÇA, A. P. M. C. Response of estuarine meiofauna assemblage to effects of fertilizer enrichment used in the sugar cane monoculture, Pernambuco, Brazil. Braz. J. Oceanog., v. 57, n. 1, p. 43-55, 2009.

SARMENTO, V. C.; BARRETO, A. F. S.; SANTOS, P. J. P. Recovery of meiofauna following a short-term disturbance on coral reefs. Biodivers. Conserv., v. 22, n. 11, p. 2645 2663, 2013

SOARES, R.; PEIXOTO, S.; BEMVENUTI, C.; WASIELESKY, W.; D'INCAO, F.; MURCIA, N.; SUITA, S. Composition and abundance of invertebrate benthic fauna in Farfantepenaeus paulensis culture pens (Patos Lagoon estuary, Southern Brazil). Aquaculture, v. 239, p. 199-215, 2004.

SOMERFIELD, P. J.; FONSÊCA-GENEVOIS, V.; RODRIGUES, A. C. L.; CASTRO, F. J. V.; SANTOS, G. A. P. Factors affecting meiofauna community structure in the Pina Basin, an urbanized embayment on the coast of Pernambuco, Brazil. J. Mar. Biol. Ass. U. K., v. 83, p. 12091213, 2003.

SUTHERLAND, T. F.; LEVINGS, C. D.; PETERSEN, S. A.; POON, P.; PIERCEY, B. The use of meiofauna as an indicator of benthic organic enrichment associated with salmonid aquaculture. Mar. Poll. Bull., v. 54, n. 8, p. 1249-1261, 2007.
THOMAS, Y.; COURTIES, C.; EL HELWE, Y.; HERBLAND, A.; LEMONNIER, H. Spatial and temporal extension of eutrophication associated with shrimp farm wastewater discharges in the New Caledonia lagoon. Mar. Pollut. Bull., v. 61, p. 387-398, 2010.

TROTT, L. A.; ALONGI, D. M. The impact of shrimp pond effluent on water quality and phytoplankton biomass in a tropical mangrove estuary. Mar. Pollut. Bull., v. 40, 11, p. 947-951, 2000.

VASCONCELOS, D. M.; SANTOS, P. J. P.; LOPES, R. Distribuição espacial da meiofauna no estuário do Rio Formoso, Pernambuco, Brasil. Atlântica, v. 26, n. 1, p. 45-54, 2004.

WALKLEY, A.; BLACK, I. A. An examination of the Degtjareff method for determining soil organic matter and proposed modification of the cromic and titration method. Soil Sci., v. 37, n. 1, p. 29-38, 1934.

WARWICK, R. M.; PLATT, H. M.; SOMERFIELD, P. J. Free-living Marine Nematodes. Part III. British Monhysterids. Synopses of the British Fauna, n. 53 (New Series). Shrewsbury: Field Studies Council, 1998.

WIESER, W. Die Beziehung zwischen Mundhoehlengstalt, Ernaehrungsweise und Vorkommen bei frelebenden marinen Nematoden. Eine oekologisch - morphologische studie. Ark. Zool., v. 2, n. 4, p. 439-484, 1953.

WOLANSKI, E.; SPAGNOL, S.; THOMAS, S.; MOORE, K.; ALONGI, D. M.; TROTT, L.; DAVIDSON, A. Modelling and visualizing the fate of shrimp pond effluent in a mangrove-fringed tidal creek. Estuar. Coast. Shelf Sci., v. 50, n. 1, p. 85-97, 2000. 
